\title{
Fen Bilimleri Öğretmen Adaylarının Pedagojik Alan Bilgilerinin Boylamsal Olarak İncelenmesi
}

\author{
Longitudinal Examination of Science Teacher Candidates’ Pedagogical \\ Content Knowledge
}

\section{İpek PÍRPÍROĞLU* Mustafa DOĞRU**}

\begin{abstract}
Öz: Bu araştırma, fen bilimleri öğretmen adaylarının Pedagojik Alan Bilgileri (PAB) gelişimlerinin desteklenmesini ve derinlemesine incelenmesini amaçlamaktadır. Nitel araştırma yaklaşımı kullanılan araştırmanın çalışma grubunu 4. sınıfında öğrenim görmekte olan altı fen bilimleri öğretmen adayı oluşturmuştur. Araştırma 2012-2013 güz ve bahar dönemi olmak üzere bir yıl boyunca devam etmiştir. Öğretmen adayları ile özel öğretim yöntemleri II, okul deneyimi ve öğretmenlik uygulaması dersleri kapsamında PAB gelişimlerine yönelik eğitimler verilmiş ve $\mathrm{PAB}$ gelişimlerine etkisi incelenmiştir. Araştırmanın verileri gözlem, görüşme ve doküman analizi aracıllğıyla toplanmıştır. Öğretmen adaylarının ders planları, mikro öğretim uygulamaları, yarı yapılandırılmış mülakatları ve sınıf içi gözlemlerinden elde edilen veriler betimsel analiz ve içerik analizi sürekli karşılaştırmalı metot ile birlikte analiz edilmiştir. Öğretmen adaylarının PAB gelişimleri Schneider ve Plasman (2011) tarafından ortaya konulan PAB gelişim yörüngesine göre değerlendirilmiştir. Verilerin analiz sonucu olarak, öğretmen adaylarının PAB gelişimlerinin kişiye özgü olarak değişim gösterdiği, bileşenler bazında ise değişimlerin doğrusal olmadığı bulunmuştur. Ancak destekleyici eğitimler sonucunda öğretmen adaylarının PAB'larının geliştiği tespit edilmiştir.
\end{abstract}

Anahtar sözcükler: Fen Bilimleri Öğretmen Adayı, Pedagojik Alan Bilgisi (PAB), PAB Gelişimi

\begin{abstract}
The aim of this research was to support and perform a detailed examination of science teacher candidates' pedagogical content knowledge (PCK). Conforming in this aim, the study group for research where a qualitative research approach was employed, consisted of six science teacher candidates in the $4^{\text {th }}$ grade. Research continued for one year during the 2012-2013 autumn and spring terms. Education related to PCK development was provided to teacher candidates under the scope of special teaching methods II, school experience and tutorage application lessons and the effect upon their PCK development was examined. Research data was collected through observation, interview and document analysis. Data obtained from the lesson plans, micro teaching applications, semi-configured interviews and interclass observations of teacher candidates was analysed employing together descriptive analysis and content analysis continuous comparative method. Science teacher candidates' PCK developments were evaluated according to Schneider and Plasman's (2011) PCK progression criteria. As a result of content analysis it was determined that the PCK developments of teacher candidates varied from person to person and that these variations are not linear in terms of their components. However, it was determined that as a result of supportive education the PCK of teacher candidates increased.
\end{abstract}

Keywords: Science Teacher Candidate, Pedagogical Content Knowledge (PCK), PCK Development

\footnotetext{
* Ph.D., Gazi Üniversitesi, Eğitim Fakültesi, İlköğretim Bölümü, Ankara. ipekpirpiroglu@gmail.com

** Yrd. Doç. Dr., Akdeniz Üniversitesi, Eğitim Fakültesi, İlköğretim Bölümü, Antalya. mustafadogru@akdeniz.edu.tr
} 
Öğrencilerin öğrenmelerini ve başarılarını etkileyen en önemli faktörlerden biri kuşkusuz öğretmenlerdir (Van Driel et al. 2001). Öğrencilerin fen alanında başarılı olmaları büyük oranda öğretmenlerine bağlı ise öğretmenler etkili öğretim yapabilmek için hangi tür bilgilere sahip olmalıdırlar? Bir öğretmen feni öğretebilmek için neleri bilmelidir? Bu sorunun yanıtı olarak dikkati çeken ve üzerinde çokça çalışılan bilgi türü ve yeterlik alanı Pedagojik Alan Bilgisidir (PAB). PAB kavramı ile ilgili ilk yayını yapan ve bu kavramı literatüre kazandıran S. Lee Shulman'a (1986-1987) göre PAB, öğretmenin alan bilgisi ve pedagoji bilgisini eşsiz bir biçimde bir araya getirip öğretim yaptığı benzersiz yapının adıdır. $\mathrm{PAB}$, bu tarihten itibaren eğitim araştırmacıları için başlı başına popüler bir çalışma alanı haline gelmiştir.

Literatürde PAB'ın genel olarak kabul edilmiş bir tanımı yoktur (Hashweh 2005; Abell 2008) ancak kabul edilen şudur ki, bir fen öğretmeni ancak güçlü bir PAB'a sahipse iyi bir öğretmen olabilir (Van Driel \& Berry 2012). Gess-Newsome ve Lederman $(1999,95)$ PAB'1 güçlü olan öğretmenin kendisine, öğrencilerinin konuyu anlamasına yardımcı olabilmek için neler yapabileceği, öğrenciler için nelerin zor olacağı, hangi materyal ve araçların kullanımının onların öğrenmelerini kolaylaştıracağı gibi sorular sorması gerekir. Dolayısıyla PAB bir konunun öğretiminde öğretmenin uzman olmasını gerektirir (Van Driel \& Berry 2012). Çünkü bir öğretmen, programın beklentileri doğrultusunda konu alan bilgisini öğrencilerin ön bilgilerini, kavram yanılgılarını, öğrenme güçlüklerini dikkate alacak biçimde, konuya uygun farklı öğretim stratejisi, yöntem ve tekniklerini seçerek, uygun ölçme ve değerlendirmede bulunacak şekilde sinıf ortamına transfer edebilmelidir.

Öğretmenlerin kendiliğinden PAB gelişimi çok geniş bir zamana yayılmakta, uzun sürmekte ve oldukça karmaşı olup, doğrusal ilerlemeyen bir süreci içermektedir (Veal \& MaKinster 1999; Magnusson et al. 1999; Abell 2008; Rozenszajn \& Yarden 2014). Ayrica gelişimler tutarlı ya da kalıcı da olmayabilmektedir. Fakat doğrudan PAB bileşenleri kullanılarak tasarlanan eğitimlerden geçen öğretmenlerin bakış açıları değişebilmektedir. PAB bileşenleri farklı araştırmacılar tarafından farklı verilse de literatürde beş bileşen öne çıkmaktadır (Shulman 19861987; Magnusson et al. 1999; Abell 2008; Park \& Oliver 2008; Kind 2009). Bu bileşenler (1) fen öğretiminin amaç ve hedefleri bilgisi, (2) program bilgisi, (3) öğrenenlerle ilgili bilgi, (4) öğretim strateji, yöntem ve teknikleri bilgisi ve (5) değerlendirme bilgisidir. Tüm bu bileşenleri içeren, fen bilimleri öğretmen ya da öğretmen adaylarının PAB'larına yönelik kullanılması önerilen gelişim modelleri (Magnusson et al. 1999; Kind 2009), araştırmacılara ve öğretmen eğitimcilerine iyi bir fen öğretimini nelerin oluşturduğu ve iyi fen öğretmenlerinin nasıl olması gerektiği konusunda yol gösterici bir yapı sunmaktadır (Abell 2008; Kind 2009). Ancak yapılan araştırmaların sonuçları genel olarak öğretmen adaylarının iyi düzeyde alan bilgisi ve pedagoji bilgisine sahip olsa bile mezun olduklarında öğrencilerin öğrenmelerini kolaylaştıracak biçimde ideal PAB seviyesine sahip olamadıklarını göstermektedir (Hashwey 2005; Kaya 2009).

Öğretmen adayları için PAB'a ilişkin bilgilerini harmanlayabilecekleri, uygulama yapma firsatı bulabilecekleri ve $P A B$ 'ın doğasının anlaşılmasına ve gelişimine yönelik eğitimlerin hazırlanması önerilmektedir. $\mathrm{Bu}$ tür eğitimlerin onların $\mathrm{PAB}$ gelişimlerine katkı sağlayacağ ifade edilmektedir (Abell 2008). Bu durum da öğretmen adaylarının PAB gelişimini temel alan derslerinde sunulacak firsatlar, onların teorik olarak gelişimlerinin tespit edilmesinde kritik bir öneme sahiptir. Schneider ve Plasman'a (2011) göre, mesleki gelişim programları aracılı̆̆ıyla sunulan firsatlar genellikle öğretmenlerin gelişimine yardımcı olmaktadır ancak bu programlar PAB gelişimine uygun olarak tasarlanmadığından istenilen düzeydeki PAB gelişimleri eksik olmaktadır. Öğretim ile ilgili karmaşık yapıların daha iyi anlaşılması için öğretmen ve öğretmen adaylarına bunu deneyimleme ve yansıtma imkânı verilerek PAB'larını geliştirilmesi önerilmektedir (Nilsson 2008). 
Öğretmenlerin $\mathrm{PAB}$ gelişimlerinin nasıl değiştiği ya da geliştiğini değerlendirebilmek oldukça zor ve karmaşıktır. Bu noktada Schneider ve Plasman (2011) fen öğretmenlerinin PAB gelişimlerinin izlediği yolu değerlendirebilmek amacıyla farklı veri tabanlarındaki toplam 361 makalenin içerik analizini yaparak "PAB Gelişim Yörüngesini" (PCK progression trajectory) teorik çerçeve olarak sunmuştur. Ancak, teorik bir yapı olan PAB gelişim yörüngesi iki kimya öğretmen adayı ile gerçekleştirilen sadece bir çalışmada sınanmış olup (Adadan \& Öner 2014) ilköğretim fen bilimleri öğretmenleri için uygunluğu henüz tespit edilmemiştir. Bu araştırmada, ilköğretim düzeyindeki fen öğretmen adaylarının PAB gelişimlerinin değerlendirilmesinde Schneider ve Plasman'ın (2011) ortaya koyduğu teorik çerçevedeki kriterler ile belirlenmesinin $\mathrm{PAB}$ gelişiminin değerlendirilmesinin teorik olarak ortaya konma ihtiyacına yardımcı olacağ 1 düşünülmektedir.

Bu çalışmada, fen bilimleri öğretmen adaylarının PAB gelişimlerinin derinlemesine incelenmesi ve PAB gelişimlerinin desteklenmesi amaçlanmaktadır. Öğretmen adaylarının sahip oldukları PAB'lar ve PAB gelişimleri için kavramsal çerçeve olarak Magnusson ve diğerlerinin (1999) PAB modeli seçilmiştir. Aynı zamanda, ilköğretim fen bilimleri öğretmen adaylarının PAB gelişimlerinin, Schneider ve Plasman'ın (2011) ifade ettiği PAB gelişimi yörüngesi kapsamında değerlendirilerek, bu teorik çerçevenin $\mathrm{PAB}$ gelişimi açısından ne düzeyde uygun olduğunu ortaya koymak amaçlanmaktadır. Bu amaca yönelik olarak araştırmanın problem cümleleri şu şekildedir:

1) İlköğretim fen bilimleri öğretmen adaylarının PAB'ları iki sömestr boyunca süren eğitimlerin etkisiyle nasıl değişmektedir?

2) Schneider ve Plasman'ın (2011) teorik olarak açıkladığı PAB gelişimi yörüngesi ilköğretim fen bilimleri öğretmen adaylarının $\mathrm{PAB}$ gelişimlerini ne derecede açıklayabilmektedir?

\section{Metod}

\section{Araştırmanın Modeli}

$\mathrm{Bu}$ araştırmada öğretmen adaylarının PAB gelişimine odaklanılmış ve nitel araştırma yaklaşımlarından bütüncül çoklu durum deseni kullanılmıştır. Durum çalışması; özel bir olgunun, olayın, durumun, programın ya da birey ve grupların derinlemesine araştırıldığı çalışmalarda tercih edilmektedir (Yin 2003; Ekiz 2009; Yıldırım \& Şimşek 2011). Öğretmen adaylarının PAB gelişimleri önce kendi içlerinde bütüncül olarak ele alınmış ve derinlemesine incelenmiş; sonra diğer öğretmen adaylarının PAB gelişimi ile karşılaştırılmıştır.

\section{Katılımcilar}

Katılımcıların belirlenmesinde olasılık temelli olmayan amaçlı örnekleme yöntemlerinden maksimum çeşitlilik tekniğinden yararlanılmıştır (Fraenkel \& Wallen 2006). Bu araştırmada öğretmen adaylarının seçimindeki en önemli kriter öğretmen adaylarının genel not ortalamasındaki çeşitlilik ve gönüllülüktür. Bir devlet üniversitesinin fen bilgisi öğretmenliği bölümü 4. sınıfına kayıtlı $(n=24)$ öğretmen adaylarının transkriptleri en yüksek puandan en düşük puana doğru sıralanmış ve iyi $(n=2)$, orta $(n=2)$, kötü $(n=2)$ kategorilerine uygun olarak toplam altı katılımcı seçilmiştir. Öğretmenlerin not ortalamaları onların alan bilgilerinin durumunu yansıtan objektif bir seçim kriteri olarak kabul edilmiştir. Çünkü alan bilgisi PAB'ın bir bileşeni olup (Magnusson et al. 1999) PAB gelişimi için ön koşuldur (Loughran et al. 2006). Araştırmada öğretmen adaylarının gerçek isimleri kullanılmamış rumuzları kullanılmıştır. Bu çalışmanın katılımcıları bir erkek ve beş kız öğretmen adayıdır ve tüm lisans (alan ve pedagoji) derslerini birlikte almıştır .

\section{Veri Toplama Araçları}

$\mathrm{Bu}$ araştırmada durum çalışmalarına uygun veri çeşitlemesi tekniğinden yaralanarak birden fazla 
veri toplama tekniği (gözlem, görüşme ve doküman analizi) kullanılmıştır (Yin 2003; Fraenkel \& Wallen 2006; Yıldırım \& Şimşek 2011). Ders planları, mikro öğretim uygulamaları, yarı yapılandırılmış mülakatlar, alan notları ve sınıf içi gözlemler veri toplama aracı olarak kullanılmıştır.

Ders Planı Hazırlama: Veri toplama aracı olarak PAB çalışmalarında sıklıkla karşımıza çıkmaktadır. Ders planları öğretmen adaylarının konuyla ilgili kavramsal anlama düzeyleri ve konuyu öğrencilere nasıl aktaracağına ilişkin önemli ipuçları sunar (Brown et al. 2013). Bu araştırmada öğretmen adaylarının hazırladıkları ders planları ile Çalık ve Aytar (2013) tarafından geliştirilen ders planı değerlendirme rubriği kullanılmıştır.

Görüşme: Durum çalışmalarının en önemli kaynaklarından biridir (Yin 2003). Öğretmen adaylarının her biriyle dönemin başlangıcında, mikro öğretim uygulamalarından önce ve sonra; sınıf içi öğretim uygulamasından önce ve sonra olmak üzere beş ayrı yarı yapılandırılmış görüşme yapılmıştır. Görüşmelerin süreleri $35 \mathrm{dk}$ ile 1,5 saat arasında değişiklik göstermiştir. Görüşme sorularıyla ilgili $\mathrm{PAB}$ alanında yayınları olan fen eğitimi uzmanı, bir ölçme ve değerlendirme alan uzmanı, bir program geliştirme uzmanı ve bir de alan uzmanı öğretim üyeleriyle görüşülmüştür, ancak uzmanlar herhangi bir değişiklik önerisinde bulunmadığından görüşme formları hazırlandığı şekliyle kullanılmıştır. Görüşmeler ses kaydına alınıp daha sonra transkriptleri çıkarılmıştır ayrıca görüşme notları tutulmuştur.

Gözlem: Araştırmada, araştırmacının araştırılan konunun gözlenmesine doğrudan katıldığ1 katılımlı gözlem yöntemi (Yin 2003; Böke 2009) tercih edilmiştir. Öğretmen adaylarının ders anlatımları oluşturulan gözlem formu kullanılarak değerlendirilmiştir. Öğretmen adaylarının hangi materyalleri, ölçme ve değerlendirme araçlarını kullandıkları, hangi etkinlikleri seçtikleri, öğrenenlerle ilgili bilgilerin ve uygulamalarının durumları vb. her ders ayrı ayrı dakika ve saniyesinde gözlem formunun gösterge kısmına kaydedilmiştir.

\section{Ölçüm Güvenirliği}

Yin (2003) bir nitel araştırmanın niteliğinin arttırılması için; (i) yapı geçerliği, (ii) iç geçerlik, (iii) dış geçerlik, (iv) güvenilirlik olmak üzere dört özelliğe dikkat edilmesi gerektiğini belirtmiştir. Araştırmada yapı geçerliğinin sağlanması birden fazla veri toplama aracının kullanılmış ve çalışma raporunun katılımcı olarak veri toplama sürecine katılmış bir kişiye okutulup görüşünün alınması yoluyla; iç geçerliğin sağlanması araştırmacı dışında öğretmen adaylarının gözlem, görüşme ve doküman analizlerinin uzman öğretim üyeleri tarafindan incelenmesi, görüş ve önerilerinin alınması yoluyla; dış geçerliğin sağlanması araştırmacının araştırma sürecinde öğretmen adaylarıyla uzun süre yüz yüze iletişim kurması ve veri çeşitlemesi kullanılmasıyla ve güvenirlik ise uzman görüşlerinin alınması ve katılımcı öğretmen adaylarının onay ve görüşlerinin alınması yoluyla gerçekleştirilmiştir.

\section{Verilerin Toplanması}

Bu araştırmada uygulamalar 2012-2013 eğitim öğretim yılı süresince toplam 21 hafta sürmüştür. Öğretmen adaylarının PAB gelişimini izlemek ve değerlendirmek için; Özel Öğretim Yöntemleri II dersinde gerçekleştirilen mikro öğretim uygulamaları yapılmış, Okul Deneyimi dersi kapsamında gözlemlerine ilişkin görüşmeler gerçekleştirilmiş, Öğretmenlik Uygulaması Dersi kapsamında ise öğretmenlerin gerçek sınıf ortamındaki sınıf içi öğretim uygulamaları gözlemlenmiştir.

Özel Öğretim Yöntemleri II dersi kapsamında; Magnusson ve diğerleri (1999) tarafından önerilen PAB bileşenlerini teorik ve uygulamalı olarak öğrencilere kazandırmak amaçlanmıştır. Öğretmen adaylarına PAB kavramı teorik olarak anlatılarak onların da bazı kaynaklardan oku- 
ma yapmaları istenmiştir. Fen eğitimin amaç ve hedefleri, programa ilişkin bilgiler, öğretim stratejileri, yöntem ve teknikleri, değerlendirme stratejileri hakkında bilgilendirmeler yapılmıştır. Daha sonra mikro öğretim uygulamaları kapsamında öğretmen adaylarından "ses" konusu ile ilgili ders planları hazırlamaları istenmiştir. Metcalf, Hammer ve Kahlich (1996), mikro öğretim uygulamalarının pedagojik yetenekleri güçlendirmede etkili bir strateji olduğuna dikkat çekmiştir. Hazırladıkları planlara uygun olarak kendi öğretimlerini gerçekleştiren öğretmen adayları, video kayıtlarını izleyerek sunumlarını $\mathrm{PAB}$ bileşenleri açısından değerlendirmiş, güçlü ve zayıf yönlerini tartışmış, gerekli düzenlemeler yapılmıştır.

Birinci yarıyılda uygulanan Okul Deneyimi dersi kapsamında; öğretmen adayları bir ilköğretim okuluna gidip fen bilimleri derslerinde gözlem yapmışlardır. Bu sayede öğrenciler, sınıf, okul ve çevre gibi faktörleri tanıma firsatı bulmuşlardır. Yaptıkları gözlemlerle ilgili görüşmeler gerçekleştirilmiştir.

İkinci yarıyılda gerçekleştirilen Öğretmenlik Uygulaması dersi kapsamında ise; öğretmen adayları gerçek sınıf ortamında öğretim uygulamaları gerçekleştirmişlerdir. Birinci yarıyıl gözlem yaptıkları aynı okulda, aynı müfredat programına bağlı ve aynı müfredat materyalleri kullanılarak öğretim yapmışlardır. Böylece PAB'ın bir boyutu olan bağlam bilgisi (context knowledge) hakkında gelişimleri ve denklikleri de sağlanmıştır (Gess-Newsome \& Lederman 1999; NargundJoshi, Park-Rogers \& Akerson 2011). Bu uygulamalardan sonra tekrar öğretmen adaylarıyla görüşmeler gerçekleştirilmiştir.

$\mathrm{Bu}$ süreçte araştırmacı tarafından planlanan eğitimlerle ilgili $\mathrm{PAB}$ alanında yayınları olan fen eğitimi uzmanı, bir ölçme ve değerlendirme alan uzmanı, bir program geliştirme uzmanı ve bir de alan uzmanı öğretim üyelerinden görüş alınmış, uygunluğuna karar verilmiştir.

\section{Verilerin Analizi}

$\mathrm{Bu}$ araştırmada, görüşmeler aracıllı̆ıyla toplanıp yazıya dönüştürülen verilerin analizi için betimsel analiz ve içerik analizi yöntemi sürekli karşılaştırmalı metot ile birlikte kullanılmışırı (Strauss \& Corbin 1990). Betimsel analiz için Magnusson ve diğerleri (1999) tarafından geliştirilen PAB modeli, kavramsal çerçeve olarak kullanılmış, modelde yer alan beş birleşen tema olarak kabul edilerek kodlanan veriler birbirleriyle ilişkilendirilip temalar altında toplanmıştır. Belirlenen temalar: Magnusson ve diğerleri (1999) tarafindan geliştirilen PAB modelinde yer alan beş bileşen olup bunlar; "Fen ögretiminin amaç ve hedefleri" "program bilgisi", "ögrretim, strateji, yöntem ve teknikleri bilgisi", "öğrenenlerle ilgili bilgi" ve "değerlendirme bilgisi"dir.

Betimsel analiz sürecinde belirlenen temalara göre özetlenen ve yorumlanan veriler, içerik analizinde daha da detaylandırılmış ve betimsel analizde fark edilemeyen kavram ve temalar bu analizle ortaya konulmuştur. Nihai analiz sonucu öğretmen adaylarının PAB gelişimleri beş ayrı tema altında Schneider ve Plasman'ın (2011) PAB gelişim yörüngesi kriter olarak alınıp yeniden değerlendirilmiş ve gelişim düzeylerine karar verilmiştir.

Schneider ve Plasman'ın (2011) her bileşen için tanımlanan gelişim yörüngesinin ilk basamaklarını deneyimsiz öğretmenler oluştururken son basamağa doğru gidildikçe uzmanlık derecesi artmaktadır. Bu araştırmada Adadan ve Öner'in (2014) iki kimya öğretmen adayının gelişimi için Schneider ve Plasman'den (2011) adapte ettikleri gelişim düzeyleri kullanılmıştır. Program bilgisi bileşenini için numaralandırma 1'den başlayarak yörüngede tanımlanan son basamak olan 2'ye kadar; fen öğretiminin amaç ve hedefleri, öğretim strateji, yöntem ve teknikleri ve değerlendirme bilgisi bileşeni için numaralandırma 1'den başlayarak yörüngede tanımlanan son basamak olan 4'e kadar; öğrenenlerle ilgili bilgi bileşeni için numaralandırma 1'den başlayarak yörüngede tanımlanan son basamak olan 5'e kadar numaralandırma yapılmıştır.

Elde edilen verilerden çıkarılacak olan anlam ve kodların güvenirliğini sağlamak için görüşme 
kayıtlarının \%25'i araştırmacı dışında iki öğretim üyesi tarafından da bağımsız olarak kodlanmıştır. Araştırmacı ile birinci ve ikinci uzman arasındaki uyum yüzdesi Cohen'in kappa katsayısı sirasıyla 0.82 ve 0.85 olarak hesaplanmıştır. Elde edilen kappa katsayıları "0.81-1.00" aralığında olduğundan "çok iyi düzeyde uyum" olduğu tespit edilmiştir. Ders planı değerlendirme rubriğinde de Cohen'in kappa katsayısı sırasıyla 0.96 ve 0.98 olarak hesaplanmıştır ve "çok iyi düzeyde uyum" bulunmuştur (Landis \& Koch 1977).

\section{Bulgular}

Fen öğretiminin amaç ve hedefleri, PAB kapsamında değerlendirilen ilk bileşendir ve diğer tüm bileşenleri etkilemektedir. Öğretmen adaylarının fen eğitimin amaç ve hedefleri ile ilgili bulgular, mikro öğretim uygulamaları ve sınıf içi uygulamaları sıralamasıyla verilmiştir.

Alan bilgisi zayıf olan öğretmen adayı Esra, dönemin başında fen eğitimin amaç ve hedeflerin neler olduğu konusunda yetersiz düzeydedir. Ses konusunun öğretimine yönelik sorulan sorularda ise konunun öğretim amacını ve hedeflerini bilmediğini ifade etmiş̧ir. Esra mikro öğretim uygulamaları ve sınıf içi tartışmalardan sonra bu konuda kendini geliştirmiştir. Gerçek sınıf içi uygulamalarda ise öğrencilerle tahmin et-gözle-açıkla tekniğini içeren basit deneyler yaptırmıştır. Bu durum Esra'nın genel olarak iyi düzeyde bir gelişim gösterdiğini ortaya koymaktadır. Schneider ve Plasman'ın (2011) PAB gelişim yörüngesinde başlangıçta 1. düzeyde iken mikro öğretim uygulamalarından sonra 4. düzeye çıkmıştır. Bu durumunu sınıf içi uygulamalarda da devam ettirmiştir.

Alan bilgisi zayıf düzeyde olan Şebnem fen eğitiminin amaç ve hedeflerini "farklı öğretim stratejileri kullanılarak fenin sevdirilmesi, deneyler ve gözlemler aracılı̆̆ıyla öğrenmenin kolaylaştırılması, başarılı olarak sınıfı geçmesi" olarak ifade etmiştir. Ancak, konuya özgü amaç ve hedefleri ise tam olarak bilmediğini, hangi sınıfta temel kavramların öğretildiğini de bilmediğini ifade etmiştir. Bu bileşenle ilgili Şebnem'in bilgi düzeyi yeterli bulunmamıştır. Daha sonra, mikro öğretim uygulamalarında kavramların günlük yaşamla ilişkisini verebilmiş, ön bilgileri yoklamıştır. Schneider ve Plasman'ın (2011) PAB gelişim yörüngesinde başlangıçta 1. düzeyde iken mikro öğretim uygulamalarından sonra 4. düzeye çıkmıştır. Bu durumunu sınıf içi uygulamalarda da devam ettirmiştir.

Alan bilgisi orta olan Ebru başlangıçta fen eğitimin amaç ve hedeflerinin "fen okuryazarı bireyler yetiştirmek, fenle ilgili yeterli bilgiye sahip olmak, fen-toplum-teknoloji ve çevreyle ilgili bilgi sahibi olmak, bilgilerini günlük hayatta kullanabilmek, başarılı olmak" olarak ifade etmiştir. Konuya özgü yapılan öğretimin amaç ve hedeflerini tam olarak bilmediğini ancak tahminleri olduğundan söz etmiştir. Ebru bu durumu değerlendirildiğinde genel anlamda orta düzeyde yeterli kabul edilmiştir. Daha sonra, mikro öğretim uygulamalarında konunun kazanımlarını verebilmiş, ön bilgileri yoklamıştır. Schneider ve Plasman'ın (2011) PAB gelişim yörüngesinde başlangıçta 1. düzeyde iken mikro öğretim uygulamalarından sonra 4. düzeye çıkmıştır. S1nıf içi uygulamasında da 4. düzeye uygun ders işlemiştir. Ancak, bazen etkinliklere yer vermesine karşın öğretmen merkezli bir kavram öğretimi yolunu tercih etmiştir.

Alan bilgisi orta düzeyde olan Hülya başlangıçta fen eğitimin amaç ve hedeflerinin "fenokuryazarı olma, doğayı anlama, fizik, kimya ve biyoloji anlama, bu bilimlerin doğayla ilişkisini ögretme" olarak ifade etmiştir. Ancak fen okuryazarı birey kavramını kısmen açıkladığı halde tutum ve değerlerden ve bilimsel süreç becerileri kavramlarıla ilgili yeterince bilgi verememiştir. Hülya'nın bu bileşendeki bilgi düzeyi kısmen yeterli bulunmuştur. Mikro öğretim öncesi yapılan görüşmelerde ve gerçek sınıf içi uygulamalardan önce ses konusuyla ilgili hangi kavramları hangi amaçlarla verileceğini doğru biçimde ifade etmiş ve planında yer vermiştir. Mikro öğretim uygulamalarında geleneksel ders işleme biçimi ağır basmıştır. Hülya öğrencilerin 
hazırbulunuşlarını dikkate almış, ön bilgileri hatırlatmıştır. Schneider ve Plasman'ın (2011) PAB gelişim yörüngesinde başlangıçta 1 . düzeyde iken mikro öğretim uygulamalarından sonra 4. düzeye çıkmıştır. Bu durumunu sınıf içi uygulamalarda da devam ettirmiştir.

Alan bilgisi iyi düzeyde olan Soner başlangıçta fen eğitiminin amaç ve hedeflerinin Esra'da olduğu gibi "başarı" kavramı etrafında yoğunlaştırmıştır ancak bunun yanı sıra fen okuryazarlığı kavramını kısmen yeterli düzeyde açıklayabilmiştir. Ayrıca fen eğitimi ve doğa ilişkisini örneklerle vurgulamıştır. Bu durumda bu bileşen ile ilgili yeterli düzeyde olduğu söylenebilir. Konuya özgü yapılan öğretimin amaç ve hedefleri konusunda hangi kavramların verileceğini ve hangi sınıfta başladığı ve hangi ünitelerle ilişkili olduğunu kısmen açıklayabilmiştir. Mikro öğretim uygulamalarında rehberlikli sorgulamaya uygun ders işlemeye gayret etmiş ancak geleneksel ders işleme biçimi daha ağır basmıştır. Buna rağmen arkadaşları ders işleyişini ve kavram öğretimini oldukça etkili bulmuştur. Schneider ve Plasman'ın (2011) PAB gelişim yörüngesinde başlangıçta 2 . düzeyde iken mikro öğretim uygulamalarından sonra 4. düzeye çıkmıştır. Bu durumunu sınıf içi uygulamalarda da devam ettirmiştir.

Alan bilgisi iyi olan Gizem fen eğitiminin amaç ve hedefleri kapsamında "BSB, FTTÇ, yaparak yaşayarak ögrenme, kendi deneylerini kendileri tasarlama ve yapma" gibi kavramlardan söz etmiştir. Aynı zamanda fen eğitiminin ve konunun günlük hayatla ilişkisi kapsamında çok sayıda ve doğru örnekler vermiştir. Gizem mikro öğretim öncesi yapılan görüşmelerde ve gerçek sınıf içi uygulamalardan önce ses konusuyla ilgili hangi kavramları hangi amaçlarla verileceğini doğru biçimde ifade etmiş ve planında da yer vermiştir. Schneider ve Plasman'ın (2011) PAB gelişim yörüngesinde başlangıçta 4 . düzeyde olup mikro öğretim uygulamalarında ve sınıf içi uygulamalarda 4. düzeyde olduğu belirlenmiştir.

Öğretmen adaylarının uygulamanın başında, mikro öğretim uygulamalarından sonra ve gerçek sınıf içi uygulamalarından sonraki fen öğretiminin amaç ve hedefleri bilgisi bileşenindeki durumlarının Schneider ve Plasman'ın (2011) PAB gelişim yörüngesine göre değerlendirilmesi Grafik 1'de verilmiştir.

Grafik 1. Öğretmen Adaylarının Fen Öğretiminin Amaç ve Hedefleri Bilgisinin Schneider ve Plasman'ın (2011) PAB Gelişim Yörüngesine Göre Değerlendirilmesi

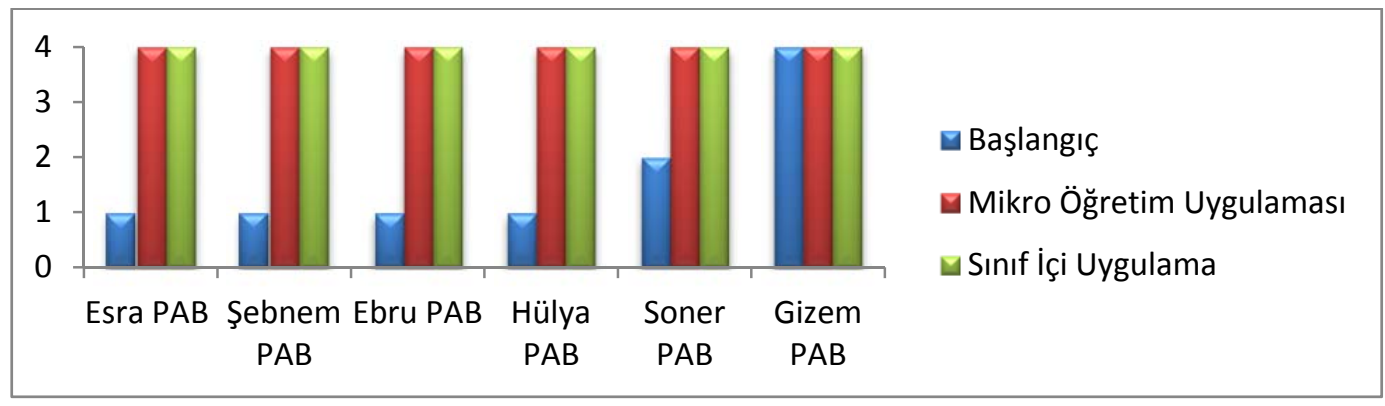

Program bilgisi bileşeni kapsamında kazanımların neler olduğu, öğrencilerin geçmişte ne öğrendiğini gelecekte ne öğreneceğini, konunun hangi konularla ve disiplinlerle ilgili olduğu hangi materyal ve kaynakların konuya uygun olduğu gibi sorulara yanıt aranmıştır.

Alan bilgisi zayıf olan Esra ilk görüşmede konuyla ilgili sorulara yanıt verememiş sadece bazı tahminlerde bulunabilmiştir. Mikro öğretim uygulamalarında önce ve sınıf içi uygulamalarda programa ilişkin bilgileri öğrendiği, bu bilgilere planlarında yer verdiği ve öğretim sırasında da uymaya çalıştığ gözlemlenmiştir. Mikro öğretim uygulamalarında programda yer almayan ama öğrencilerin anlamasında yardımcı olacak çok sayıda materyali sınıf ortamına getirmiştir. Schneider ve Plasman'ın (2011) PAB gelişim yörüngesine göre başlangıçta hiçbir bilgi bilmediği, 
ancak mikro öğretim ve sınıf içi uygulamalarda gelişim göstermiş olup 2. düzeyde olduğu belirlenmiştir. Ancak bu kriter başlangıçta hiçbir şey bilmemesi sıfır olarak puanlanamaması PAB gelişim yörüngesinin gelişimi yeterli düzeyde açıklamadığı düşünülmektedir.

Alan bilgisi zayıf olan Şebnem'in de başlangıçta hangi kavramın, hangi sınıf düzeyinde verileceğini tam olarak bilmediği tespit edilmiştir. Ancak mikro öğretim uygulamalarında ve sınıf içi uygulamalarında kazanımları ve kavramları doğru olarak ifade edebilmiştir. Her iki uygulamada da bu bileşen bazında gelişim göstermiştir. Schneider ve Plasman'ın (2011) PAB gelişim yörüngesine göre başlangıçta bilgilerinden tam olarak emin olmadığı için 1. düzeyde, mikro öğretimde ve sınıf içi uygulamalarında 2. düzeyde olduğu tespit edilmiştir.

Alan bilgisi orta düzeyde olan Ebru başlangıçta hangi kavramların, hangi konuların bu ünitede yer aldığını tam olarak ifade edememiş, sadece tahminlerde bulunmuştur. Ayrıca diğer ünitelerle olan ilişkisini de açıklayamamıştır. Ancak hem mikro öğretim hem de sınıf içi uygulamalarında uygun kavramları doğru biçimde verebilmiştir. Schneider ve Plasman'ın (2011) PAB gelişim yörüngesine göre başlangıçta bilgilerinden tam olarak emin olmadığı için 1. düzeyde, mikro öğretimde ve sınıf içi uygulamalarında 2. düzeyde olduğu tespit edilmiştir.

Alan bilgisi orta düzeyde olan Hülya başlangıçta hangi kavram ve olguların, hangi materyallerin kullanılacağını tam olarak bilemediğini ifade etmiştir. Mikro öğretim uygulamalarında programın sarmal yapısına uygun ders işlemiş, uygun materyalleri sınıf ortamında kullanmıştır. Schneider ve Plasman'ın (2011) PAB gelişim yörüngesine göre başlangıçta bilgilerinden tam olarak emin olmadığı için 1. düzeyde, mikro öğretimde ve sınıf içi uygulamalarında 2. düzeyde olduğu tespit edilmiştir.

Alan bilgisi iyi düzeyde olan Soner başlangıçta bu konuyla ilgili hangi kavram ve olguların, hangi materyallerin kullanılacağını tam olarak bilemediğini ifade etmiştir. Diğer konularla ya da disiplinlerle de ilişki kuramamıştır. Soner, mikro öğretim uygulamalarında ciddi bir gelişim göstermiştir ve planında belirttiği gibi tüm kazanımları vermiş, tüm materyalleri doğru kullanmıştır. Sınıf içi uygulamalarda ise farklı materyaller ve kaynaklar kullandığı tespit edilmiştir. Başlangıçta bu bileşenler konuyla ilgili yetersiz durumda iken sürecin sonunda yeterli hale gelmiştir. Schneider ve Plasman'ın (2011) PAB gelişim yörüngesine göre başlangıçta bilgilerinden tam olarak emin olmadığı için 1. düzeyde, mikro öğretimde ise yeterli düzeyde bildiği ve uyguladığı için 2. düzeyde olduğu tespit edilmiştir. Ancak Soner için de PAB gelişim yörüngesi gelişimini yeterli düzeyde açıklamadığı düşünülmektedir.

Alan bilgisi iyi olan Gizem'in başlangıçta programda önerilen kavramlardan bildiği ancak hangi materyallerin tam olarak kullanıldığını hatırlayamadığ maddenin tanecikli yapısı ve duyu organları konularıyla olan ilişkisini yalnızca Gizem ifade etmiştir. Hem mikro öğretimler de hem de derste programda yer alan olgu ve kavramlara planlarında yer vermiş, doğru biçim de derslerinde kullanmıştır. Ayrıca farklı kaynaklardan konuya uygun etkinlikler bulup uygulamış ve kavramları çok sayıda ve uygun materyalle işlemiştir. $\mathrm{Bu}$ durumda Schneider ve Plasman'ın (2011) PAB gelişim yörüngesine göre başlangıçta bilgilerinden tam olarak emin olmadığı için 1. düzeyde, mikro öğretimlerde ve sınıf içi uygulamalarda ise 2. düzeydedir. Yine Gizem'in bu bileşendeki PAB gelişimini, PAB gelişim yörüngesinin tam olarak karşılamadığı düşünülmektedir.

Öğretmen adaylarının uygulamanın başında, mikro öğretim uygulamalarından sonra ve gerçek sınıf içi uygulamalarından sonraki program bilgisi bileşenindeki durumlarının Schneider ve Plasman'in (2011) PAB gelişim yörüngesine göre değerlendirilmesi Grafik 2'de verilmiştir. 
Grafik 2. Öğretmen Adaylarının Program Bilgisinin Schneider ve Plasman'ın (2011) PAB Gelişim Yörüngesine Göre Değerlendirilmesi

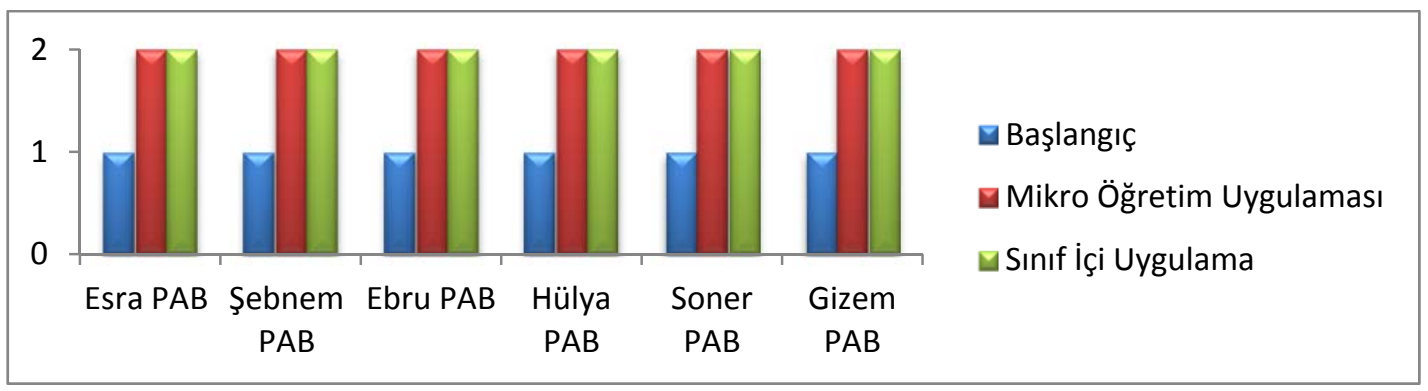

Öğrenenlerle ilgili bilgi, bileşeni kapsamında öğrencilerin ön bilgileri, öğrenmekte zorlanacakları kavramlar ve olası kavram yanılgılarına ilişkin bilgileri incelenmiştir.

Alan bilgisi zayıf olan Esra öğrencilerin ön bilgilerinin neler olması gerektiğini ve öğrencilerin olası kavram yanılgılarını bilmediğini ifade etmiştir. Öğrencilerin zorlanabilecekleri yerlerin geçmişte kendisinin de zorlandığı yerler olabileceğini ifade etmiştir. Esra, sınıf içi uygulamalarda ise öğrencilerin olası kavram yanılgılarını ve hangi ön bilgilere sahip olması gerektiğine ders planında yer vermiştir. Ancak ders sırasında gelen bir soru üzerine "Sesin yüksekliği ile tınısına aynı şey diyebiliriz çocuklar" gibi kavram yanılgısı içeren bir cümle kurmuştur. Schneider ve Plasman'ın (2011) PAB gelişim yörüngesine göre başlangıçta 2 . düzeyde, mikro öğretim uygulamalarında ve sınıf içi uygulamalarda ise 4. düzeyde olduğu tespit edilmiştir.

Alan bilgisi zayıf olan Şebnem de mikro öğretim uygulamalarından önce yapılan görüşmelerde öğrencilerin ön bilgilerinin neler olması gerektiğini, hangi kavramları öğretirken güçlük yaşayabileceğini ve olası kavram yanılgılarını bilmediğini ifade etmiştir. Yalnızca öğrencilerin sesin yüksekliği ve şiddetini karıştırabileceklerini ifade etmiştir. Mikro öğretim uygulamalarında gösteri deneyleri yapan Şebnem öğrencilerini gözlem yaptırmaya yönlendirmiş ve öğrencilerin farklılıkları göz önüne alarak soyut konuları somutlaştırma yoluna gitmiştir. Ancak konuyu anlatırken bir kavram yanılgısı içeren "Çocuklar ses işte madde gibi bir şeydir" cümlesini kurmuştur. Schneider ve Plasman'in (2011) PAB gelişim yörüngesine göre başlangıçta 2. düzeyde, mikro öğretim uygulamalarında ve sınıf içi uygulamalarda ise 4. düzeyde olduğu tespit edilmiştir.

Alan bilgisi düzeyi orta olan Ebru da ders öncesinde konuya ilişkin kavramların, ön bilgilerin, kazanımların neler olduğunu ve olası kavram yanılgıları ve öğrenme güçlüklerini net olarak bilmediğini ifade etmiştir. Ancak mikro öğretim uygulamalarında öğrencilerin soru cevap yoluyla ön bilgilerini yoklamış, öğrencilerin dikkatini çekmek ve öğrenme güçlüğünün önüne geçmek için çok sayıda materyal kullanmış ve sesin nasıl duyulduğunu anlatırken duyu organları konusuna değinmiştir. Schneider ve Plasman'ın (2011) PAB gelişim yörüngesine göre başlangıçta 2 . düzeyde, mikro öğretim uygulamalarında ve sınıf içi uygulamalarda ise 4. düzeyde olduğu tespit edilmiştir.

Alan bilgisi orta düzeyde olan Hülya da başlangıçta bu bileşenle ilgili bilgileri tam olarak bilmemekte sadece tahminler yürütmüsstür. Mikro öğretim uygulamaları sırasında tüm kavramları doğru olarak vermesine karşın rezonans ve yankı kavramları ders planında yer almadığı halde dersinde işlemiştir. Schneider ve Plasman'ın (2011) PAB gelişim yörüngesine göre başlangıçta 2. düzeyde, mikro öğretim uygulamalarında ve sınıf içi uygulamalarda ise 4. düzeyde olduğu tespit edilmiştir.

Alan bilgisi iyi düzeyde olan Soner'in başlangıçta öğrencilerin ön bilgileri, olası kavram 
yanılgıları ve öğrenme güçlükleriyle ilgili bazı bilgilere sahip olduğu tespit edilmiştir. Ancak Soner, mikro öğretim uygulamalarında bu bileşenle ilgili dersini tam olarak planlayarak gelmiş, tüm etkinlikleri uygun biçimde yapmıştır. Sınıf içi uygulamalarda bu bileşendeki kriterlere uygun ders planı hazırlamış ve yeni etkinlikler seçmiştir. Sınıfında da öğrencilerin sahip olabilecekleri kavram yanılgılarını ortaya çıkarmaya çalışan sorular sormuş ve etkinliklerle doğru kavramları öğrenmeye yönlendirmiştir. $\mathrm{Bu}$ durumlar değerlendirildiğinde Schneider ve Plasman'ın (2011) PAB gelişim yörüngesine göre başlangıçta 2. düzeyde, mikro öğretimlerde 4. ve sınıf içi uygulamalarda 5. düzeyde olduğu belirlenmiştir.

Alan bilgisi iyi düzeyde olan Gizem başlangıçta öğrencilerin ön bilgileri, olası kavram yanılgıları ve öğrenme güçlükleriyle ilgili bilgilere sahip olduğu tespit edilmiştir. Diğer öğretmen adayları gibi Gizem'de geçmişte kendi zorlandığı yerlerde öğrencilerin de zorlanacağını düşünmüş̧ür. Gizem bu bileşenle ilgili, dersini hem mikro öğretim uygulamalarında hem de sınıf içi uygulamalarda tam olarak planlayarak gelmiş, tüm etkinlikleri uygun biçimde yapmış ve öğrencilere deneyim yaşatma yoluyla konuyu öğretmiştir. Bu durumlar değerlendirildiğinde Schneider ve Plasman'ın (2011) PAB gelişim yörüngesine göre başlangıçta 3. düzeyde, mikro öğretimlerde ve sınıf içi uygulamalarda 5. düzeyde olduğu belirlenmiştir.

Öğretmen adaylarının uygulamanın başında, mikro öğretim uygulamalarından sonra ve gerçek sınıf içi uygulamalarından sonraki öğrenenlerle ilgili bilgi bileşenindeki durumlarının Schneider ve Plasman'ın (2011) PAB gelişim yörüngesine göre değerlendirilmesi Grafik 3'te verilmiştir.

Grafik 3. Öğretmen Adaylarının Öğrenenlerle İlgili Bilgisinin Schneider ve Plasman'ın (2011) PAB Gelişim Yörüngesine Göre Değerlendirilmesi

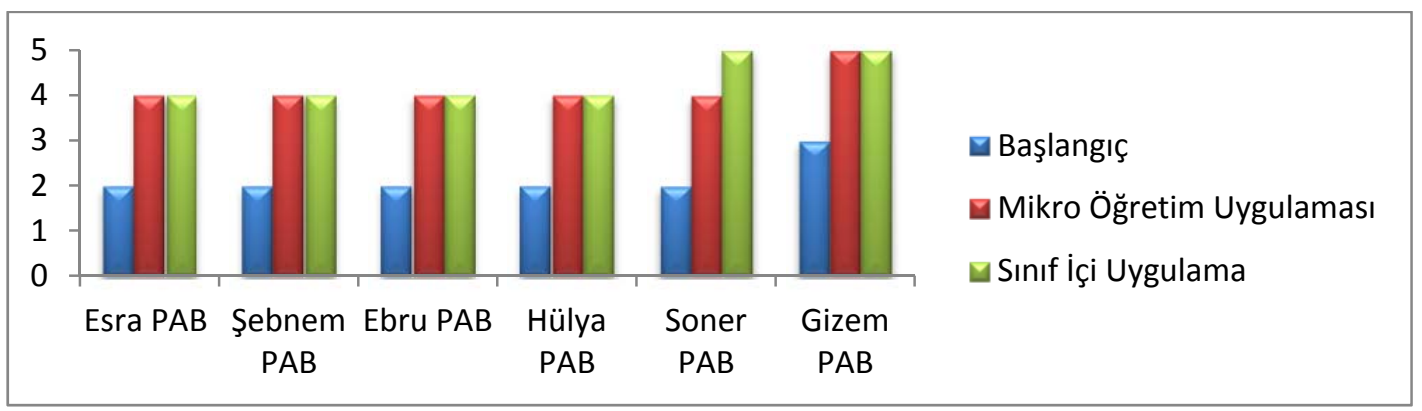

Öğretim strateji, yöntem ve teknikleri bilgisi, bileşeni kapsamında öğretmen adaylarının öğretim yöntem, teknik ve stratejilerinin hangilerinin fene özgü hangilerinin ise konuya özgü olduğu sorulmuştur. Öğretmen adaylarının seçimlerinde hangi hususları dikkate aldıkları ve süreç içinde tercihlerinde herhangi bir değişim olup olmadığına bakılmıştır. Öğretmen adaylarının tamamı fene özgü strateji, yöntem ve tekniklerine uygun örnekler (5E, argümantasyon vb.) vermiş ancak konuya özgü strateji, yöntem ve teknikleri hatırlayamamışlardır.

Alan bilgisi zayıf olan Esra başlangıçta gösteri deneyleri ve düz anlatım yapabileceğini ifade etmiştir. Çok uygun bir yöntem seçip seçemeyeceğini ya da neye göre karar verebileceğini bilmediğini de belirtmiştir. Mikro öğretim uygulamalarında ise powerpoint sunusu kullanarak düz anlatım yöntemini kullanmıştır. Etkinliklerde gösteri deneyini tercih etmiştir, ancak çok sayıda gösteri deneyi yapması ve materyal kullanması dersi kısmen akıcı hale getirmiştir. Sınıf içi uygulamalarda ise tahmin et-gözle-açıkla tekniğinden yararlanmış ve daha çok öğrenciyi aktif hale getiren uygulamalar yapmaya gayret etmiştir, ancak yine de geleneksel yöntemin ağırlıklı olduğu gözlenmiştir. Schneider ve Plasman'ın (2011) PAB gelişim yörüngesine göre başlangıçta 1. düzeyde, mikro öğretim uygulamalarında 2 . ve sınıf içi uygulamalarda 3 . düzeyde 
olduğu belirlenmiştir.

Alan bilgisi zayıf olan Şebnem başlangıçta konuyla ilgili hangi yöntem ya da tekniğin uygun olabileceğini bilmediği ancak deneylerle anlatılabileceğini ifade etmiştir. Mikro öğretim uygulamalarında gösteri deneyleri yapmıştır ancak, kendi yaratıcılığına dayalı hazırlamış olduğu materyaller beğenilmiştir. Sınıf içi uygulamalarda da benzer biçimde ders işlemiş, genel olarak öğretmen merkezli olmayı tercih etmiştir. Schneider ve Plasman'ın (2011) PAB gelişim yörüngesine göre başlangıçta 1. düzeyde, mikro öğretim uygulamalarında 2. ve sınıf içi uygulamalarda 3 . düzeyde olduğu belirlenmiştir.

Alan bilgisi orta düzeyde olan Ebru başlangıçta dersini yapılandırmacıllı̆ı temel alan bir yöntemle işleyebileceğini ifade etmiştir. Ancak mikro öğretim uygulamalarında daha çok soru cevap biçimindeki sunuş yolunu tercih etmiştir. Rehberlikli sorgulamayı ders planında tasarlamış olmasına rağmen ders sırasında güçlük yaşamıştır. Sınıf içi uygulamalarında ise $5 \mathrm{E}$ yöntemini tercih etmiş ancak zaman zaman öğretmen merkezli ders işlemiştir. Schneider ve Plasman'ın (2011) PAB gelişim yörüngesine göre başlangıçta 2. düzeyde, mikro öğretim ve sinıf içi uygulamalarda 3. düzeyde olduğu belirlenmiştir.

Alan bilgisi orta düzeyde olan Hülya başlangıçta fene ve konuya özgü çok sayıda öğretim yönteminin (örneğin drama, argümantasyon...) adını söylemiş ama konularla eşleştirememiştir. Mikro öğretim uygulamalarında genellikle öğrencileri aktif olarak derse katmaya çalışsa da öğretmen merkezli olarak dersi işlemiş, sunumlar üzerinden gitmiş, videolar izletmiş ve etkinlik yaptırmıştır. Schneider ve Plasman'ın (2011) PAB gelişim yörüngesine göre başlangıçta 1. düzeyde, mikro öğretim uygulamalarında 2. ve sınıf içi uygulamalarda 3. düzeyde olduğu belirlenmiştir.

Alan bilgisi iyi düzeyde olan Soner başlangıçta 5E, beyin firtınası, gösterip yaptırma, basit malzemelerle deney yaptırma gibi yöntem ve tekniklerden bahsetmiştir. Soner mikro öğretim uygulamalarında hem de sınıf içi uygulamalarında rehberlikli sorgulama yaklaşımını kullanmıştır, ancak zaman zaman öğretmen merkezli ders işlemiştir. Sınıf içi uygulamalarında ise 5E öğrenme metodunu tercih etmiştir. Schneider ve Plasman'ın (2011) PAB gelişim yörüngesine göre başlangıçta 2. düzeyde, mikro öğretim ve sınıf içi uygulamalarda 3. düzeyde olduğu belirlenmiştir.

Alan bilgisi iyi düzeyde olan Gizem başlangıçta $5 \mathrm{E}$, argümantasyon ve oyunla öğretimin uygun olduğunu düşündüğünü nedenleriyle açıklamıştır. Gizem hem mikro öğretim hem de sınıf içi uygulamalarında 5E modelini kullanmıştır. Etkinlikleri öğrencilere yaptırmış, süreçte verileri öğrenciler toplamış olsa da sonuçları yorumlayamayacaklarını düşündüğünden kendisi ifade etmiştir. Gizem de Schneider ve Plasman'in (2011) PAB gelişim yörüngesine göre başlangıçta 2. düzeyde, mikro öğretim uygulamalarında 3 . ve sınıf içi uygulamalarda 4. düzeyde olduğu belirlenmiştir.

Öğretmen adaylarının uygulamanın başında, mikro öğretim uygulamalarından sonra ve gerçek sınıf içi uygulamalarından sonraki öğretim strateji, yöntem ve teknikleri bilgisi bileşenindeki durumlarının Schneider ve Plasman'ın (2011) PAB gelişim yörüngesine göre değerlendirilmesi Grafik 4'te verilmiştir. 
Grafik 4. Öğretmen Adaylarının Öğretim Strateji, Yöntem ve Teknikleri Bilgilerinin Schneider ve Plasman'ın (2011) PAB Gelişim Yörüngesine Göre Değerlendirilmesi

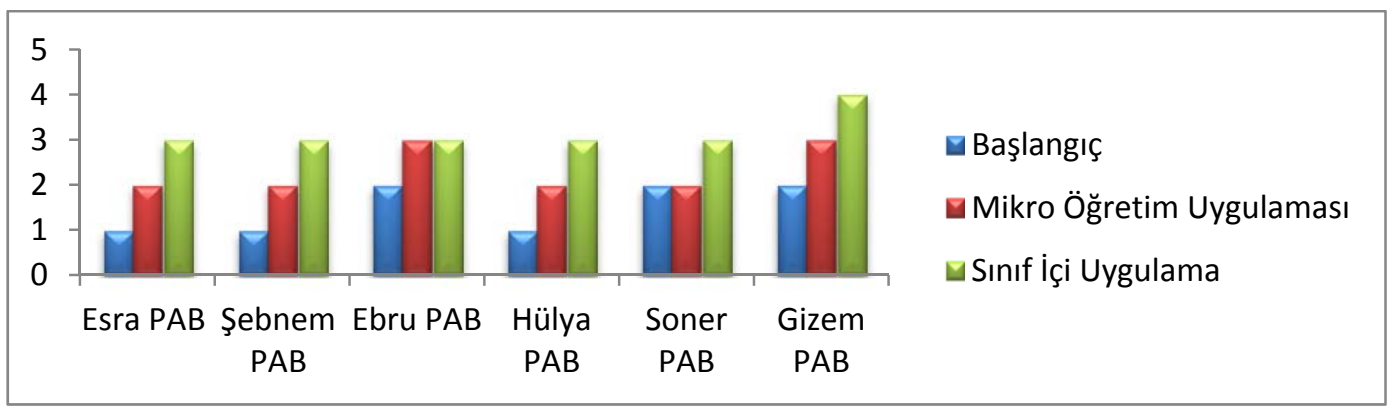

Değerlendirme bilgisi bileşeni kapsamında öğretmen adaylarının ürüne mi yoksa sürece mi dönük değerlendirmeler yaptıkları ve eğitimler sonrasında tercihlerinde herhangi bir değişim gösterip göstermedikleri incelenmiştir.

Alan bilgisi zayıf olan Esra başlangıçta geleneksel ve tamamlayıcı değerlendirme tekniklerini söyleyebilmiştir. Konuya uygun olan değerlendirme tekniğinin hangisi/hangileri olabileceği sorulunca ise, hangisinin uygun olacağını düşünmediğini fakat test yapmayı düşündüğünü ifade etmiştir. Mikro öğretim uygulamalarında değerlendirme olarak önce hazırladığ 1 sunumun son bölümünde eklediği sorularla değerlendirmiştir. Ayrıca test ve boşluk doldurma sorularından oluşan bir çalışma kağıdı hazırlamıştır. Sınıf içi uygulamalarında ise yine çalışma kağıdı hazırlamış, çalışma kağıdına yapılandırılmış grid de eklemiştir. Ancak ders sırasında kazanımları dikkate aldığı ve sorduğu sorulardan büyük çoğunluğunun ezber bilgiyi yoklayan basit sorular olduğu tespit edilmiştir. Schneider ve Plasman'in (2011) PAB gelişim yörüngesine göre başlangıçta 1. düzeyde, mikro öğretim ve sınıf içi uygulamalarda 2. düzeyde olduğu belirlenmiştir.

Alan bilgisi zayıf olan Şebnem başlangıçta genel olarak geleneksel ölçme ve değerlendirme tekniklerine örnek vermiştir. Tamamlayıcı ölçme ve değerlendirme tekniklerini kullanmayı tam olarak bilmediğini ifade etmiştir. Mikro öğretim uygulamalarında konu içinde soru cevap yöntemini kullanmış ancak konuya özgü herhangi bir değerlendirme yapmamıştır. Ders anlatımı sırasında sorduğu sorular kazanımları dikkate alan kısmen üst düzey ancak genel anlamda basit sorulardan hazırlamıştır. Sınıf içi uygulamalarında ise geleneksel ölçme ve değerlendirme yaklaşımına uygun olarak hazırladığı çalışma kağıdını kullanmıştır. Schneider ve Plasman'ın (2011) PAB gelişim yörüngesine göre başlangıçta 1. düzeyde, mikro öğretim ve sınıf içi uygulamalarda 2. düzeyde olduğu belirlenmiştir.

Alan bilgisi orta düzeyde olan Ebru başlangıçta hem geleneksel hem de tamamlayıcı ölçme ve değerlendirme tekniklerine örnekler verebilmiştir. Ancak konuya özgü hangi tekniği kullanacağını bilemediğini ifade etmiştir. Mikro öğretim uygulamalarında konu içinde soru cevap biçiminde, konu sonunda boşluk doldurma, doğru yanlış, çoktan seçmeli sorulardan oluşan detaylı bir çalışma kağıdı kullanmıştır. Sınıf içi uygulamalarda da benzer bir yol izlemiştir. Schneider ve Plasman'ın (2011) PAB gelişim yörüngesine göre başlangıçta 1. düzeyde, mikro ögretim ve sınıf içi uygulamalarda 2 . düzeyde olduğu belirlenmiştir.

Alan bilgisi orta düzeyde olan Hülya da başlangıçta konuya özgü olmayan ancak fene özgü değerlendirme tekniklerinin büyük çoğunluğuna örnek vermiştir. Mikro öğretim uygulamalarında sınıf içi soru cevap yoluyla değerlendirmelerde bulunmuş ancak konu sonunda değerlendirme yapmamıştır. Sınıf içi uygulamalarda ise hem geleneksel ölçme ve değerlendirmeyi kapsayan çalışma kağıdı hazırlamış hem de yapılandırılmış grid kullanmıştır. Ancak hazırlanan soruların ezber bilgiyi ölçen basit düzeydeki sorular olduğu görülmüştür. Schneider ve 
Plasman'ın (2011) PAB gelişim yörüngesine göre başlangıçta ve mikro öğretim uygulamalarında 1. düzeyde, sınıf içi uygulamalarda 2. düzeyde olduğu belirlenmiştir.

Alan bilgisi iyi düzeyde olan Soner de başlangıçta geleneksel ve tamamlayıcı değerlendirme tekniklerini söyleyebilmiştir. Soner hem mikro öğretim uygulamalarında hem de sınıf içi uygulamalarda tanılayıcı dallanmış ağaç, v-diyagramı ve test kullanmıştır. Schneider ve Plasman'ın (2011) PAB gelişim yörüngesine göre başlangıçta 2. düzeyde, mikro öğretim ve sınıf içi uygulamalarda 3. düzeyde olduğu belirlenmiştir.

Alan bilgisi iyi düzeyde olan Gizem hem başlangıçta, hem mikro öğretim uygulamalarında portfolo, balık kılçığı ve çalışma yaprağı kullanacağını ifade etmiştir. Schneider ve Plasman'ın (2011) PAB gelişim yörüngesine göre Gizem'in durumunu açıklamakta güçlük yaşanmıștır. Çünkü Gizem hem sürece dönük değerlendirme tekniklerini hem de geleneksel değerlendirme tekniklerini bir arada kullanmıştır. Ancak gerek Gizem'in gerek yapılandırmacılığı temel alan yaklaşımları kullanması gerekse sürecin değerlendirilmesinin öneminden bahsetmesi ve dersinde ezberden uzak sorgulamayı temel alan sorular sorması nedeniyle Gizem'i her üç durumda 3. düzeyde olduğu kabul edilmiştir. Schneider ve Plasman'ın (2011) PAB gelişim yörüngesi bu bileşen üzerinde değerlendirme yapmakta yeterli olmadığı düşünülmektedir.

Öğretmen adaylarının uygulamanın başında, mikro öğretim uygulamalarından sonra ve gerçek sınıf içi uygulamalarından sonraki değerlendirme bilgisi bileşenindeki durumlarının Schneider ve Plasman'ın (2011) PAB gelişim yörüngesine göre değerlendirilmesi Grafik 5'te verilmiştir.

Grafik 5. Öğretmen Adaylarının Değerlendirme Bilgilerinin Schneider ve Plasman'ın (2011) PAB Gelişim Yörüngesine Göre Değerlendirilmesi

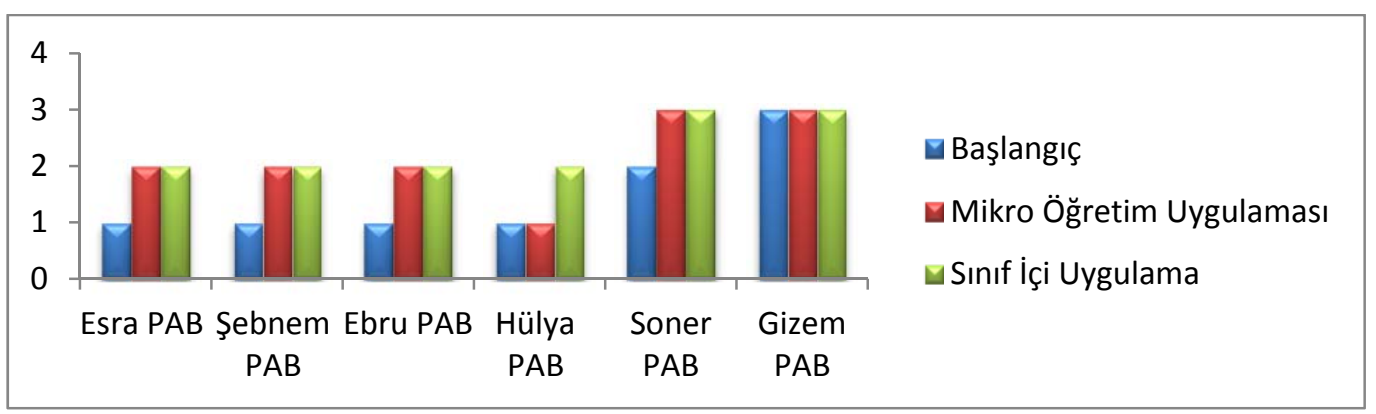

\section{Sonuç ve Tartışma}

Öğretmen adayları 4. sınıfa program, değerlendirme, alan bilgisi, öğretim stratejileri derslerini başarıyla tamamlamış oldukları halde birinci dönemin başlangıcında yapılan görüşmeler ve ders planlarından elde edilen verilere göre değerlendirildiğinde PAB'larında eksiklikler olduğu tespit edilmiştir. Mikro öğretim uygulamaları sırasında da PAB bileşenlerini konunun öğretiminde ya da bir dersin planlanmasında uygun biçimde harmanlayamadıkları görülmüştür. Bu durumda bir konunun öğretiminde ya da planlanmasında $\mathrm{PAB}^{\prime}{ }_{1}$ bütüncül olarak kullanabilme bakış açısının eksikliğinden kaynaklandığı düşünülmektedir. Çünkü bu derslerden iyi notlarla geçmiş oldukları halde PAB çerçevesinden bakıldığında, yeterli düzeyde olmadıkları net olarak görülmektedir.

Mikro öğretim uygulamalarından sonraki durumları incelendiğinde ise öğretmen adayların PAB'larında ciddi bir gelişim gözlenmiştir. Ancak bu gelişim katılımcılara ve her bileşenin türüne göre farklılık göstermiştir. PAB bileşenlerinin her biri katılımcılara göre farklılık göstermesi diğer araştırmacıların sonuçlarıyla da tutarlılık göstermektedir (Magnussonet et al. 1999; De Jong et al. 2005; Schneider \& Plasman 2011; Rozensjanj \& Yarden, 2014). Bu farkl1lklar; alan bilgisi ve pedagojik bilgi gelişimi (Magnussonet et al. 1999; De Jong et al. 2005), önceki deneyimlerinden fen öğretimlerine yönelik yeterlik inançları (Hashweh 2005; Park \& 
Oliver 2008) ve mesleki gelişim programlarının bağlamı, içeriği ve kullanılan stratejilerin farklılığından kaynaklandığı bu araştırmada ortaya çıkan sonuçlardandır. Öğretmen adaylarının sınıflarında işlenen konu alan bilgisi ve pedagoji stratejilerini birleştirmek için çabaladıkları tespit edilmiştir. Veal, Tippins ve Bell'in (1999) fizik öğretmen adaylarının sınıf içi deneyimleri arttıkça öğretmen adaylarının daha çok öğrenci merkezli uygulamalar yapabildiği bu araştırmayla da kanıtlanmıştır.

Fen eğitiminin amaç ve hedefleri bileşeninin gelişimi oldukça az sayıda çalışmada incelenmiş olup bu çalışmalar ortaöğretim fen öğretmen adaylarına yöneliktir (De Jong \& Van Driel 2004; Nilsson 2008). Brown, Friedrichsen ve Abell'in (2012), dört biyoloji öğretmen adayının PAB gelişimini izledikleri çalışmada fen eğitiminin amaç ve hedefleri bileşeninde değişime karşı direnç gösterdiğini tespit etmiştir. Bu çalışmada da Soner ve Gizem dişındaki öğretmen adayları için benzer bir sonuç tespit edilmiştir. Bununla birlikte, öğretmen adayları süreç içerisinde Schneider ve Plansman'ın (2011) PAB gelişim yörüngesine göre önemli gelişimler göstermiştir (Grafik 2). Magnusson ve diğerleri (1999) ile Friedrichsen, Abell, Pareja, Brown, Lankford ve Volkmann'a (2009) göre bu bileşen diğer tüm PAB bileşenlerini etkilemektedir. Bu araştırmada da öğretmen adaylarının fen öğretimin amaç ve hedeflerindeki gelişim onların öğretim stateji, yöntem ve tekniklerini, değerlendirme türü seçimini ve programa ilişkin uygulamalarındaki öğretmen merkezli ve sadece başarının hedeflenmesinden öğrenci merkezli anlayışa yönlendirmiştir. Öğretmen adaylarının fene yönelik oryantasyonlarındaki bu değişimin nedeni, öğretmen adaylarının PAB gelişimini destekleyen eğitimlerden olarak yorumlanabilir. Bir dönem boyunca neden fen öğrettiklerinin ve feni öğretebilmek için neye ihtiyaçları olduğunun tartışılması, uygulamalar yapmaları ile deneyim kazanmaları, öğretim programını daha yakından tanımalarında etkili olmuştur.

Program bilgisi bileşeni Null'e (2011) göre eğitimin kalbi olup amaçların ve hedeflerin birleştirildiği ve neyin öğretilmesi gerektiğini içerir. Ancak öğretmen adaylarının program bilgisi bakımından yetersiz olduğu tespit edilmiştir (Grafik 3). Schneider ve Plasman'ın (2011) PAB gelişim yörüngesine göre öğretmen adaylarının tamamı başlangıçta ve hatta mikro öğretim uygulamaları sırasında birinci (en düşük) düzeydedir. Sınıf içi uygulamalarda ise, PAB gelişim yörüngesine göre en yüksek olan ikinci düzeye geldikleri görülmüştür. Ancak bu gelişim yörüngesi bu bileşen açısından, hiçbir bilgi sahibi olunmaması durumunda da kısmen bilgi sahibi olunması durumunda da aynı düzeyde olduklarını varsayması nedeniyle, gelişimi tam ifade etmemiş görünmektedir. Araştırmanın bu bileşenle ilgili sonuçları öğretmen adaylarının programa yeterince hâkim olmaları bakımından Friedrihsen ve diğerleri (2009) ve Kaya'nın (2009) çalışma bulguları ile uyumluluk göstermektedir. Deneyim arttıkça öğretmenlerin müfredatla ilgili bilgilerinin artması bakımından ise Schneider ve Plasman (2011) ile uyumluluk göstermektedir. Ayrıca, konuya özgü program bilgilerinin artması ile materyallere ilişkin bilgilerinin artması yönüyle de Park ve Oliver (2008) ile benzerlik göstermektedir.

Öğrenenlerle ilgili bilgi bileşeni bakımından öğretmen adayları; Schneider ve Plasman'ın (2011) PAB gelişim yörüngesine göre birinci, ikinci ve üçüncü düzeyinde yer almışlardır. Öğretmen adaylarından bazıları derste kavram yanılgısı içeren cümleler kurmuşlardır. McComas'a (2014) göre bir fen öğretmeni öğrencilerin yanlış kavramaları hakkında bilgi sahibi olmalı ve dersinde ona uygun öğretimi yapmalıdır. Öğretmen adaylarının mikro öğretim uygulamalarında öğrencilerin ön bilgilerini test etmeden ve değerlendirmeden öğretime başlaması ve sınıf içi uygulamalarda güçlük yaşaması bakımından Morrison ve Lederman'ın (2003) öğretmenlerin derse başlarken öğrencilerin ön bilgilerini değerlendirmede zorluk yaşadıkları, derse başlamadan önce herhangi bir ön test ve ya görüşme yapmadıkları ve De Jong ve Van Driel'ın (2004) derslerden önce öğretmen adaylarının konuyla ilgili öğrenme güçlüklerinin neler olduğunu na- 
diren bildiklerini sonucuyla da uyumludur. Genel olarak öğretmen adayları da bu bileşen bakımından PAB'ları gelişmiştir (Grafik 4). Ancak, Brown ve diğerleri (2012) ortaöğretim öğretmen adaylarının ders planı hazırlarken öğrencilerle ilgili derinlemesine düşünmeden ya da yeni öğrenecekleri konuda yaşayacakları güçlükler hakkında yeterince düşünmediklerini ifade etmiştir. Bu araştırmada da ilk hazırladıkları planlarda oldukça yetersiz, mikro öğretimlerle kısmen gelişmiş, ancak uygulamalarda tam olarak dikkate aldıkları tespit edilmiştir.

Öğretim strateji, yöntem ve teknikleri bilgisi bileşeni bakımından öğretmen adayları başlangiçta konuya özgü hangi öğretim strateji, yöntem ya da tekniklerinin uygun olduğunu düşünememişlerdir. $\mathrm{Bu}$ durum program bilgilerindeki eksiklikler öğretmenlerin öğretim stratejisi tercihlerini de sınırlandırdığı şeklinde yorumlanmıştır. Schneider ve Planman'ın (2011) PAB gelişim yörüngesine göre öğretmen adayları bu bileşen bakımından gelişim göstermiştir (Grafik 5). Ancak öğretmen adaylarının hiç biri bir öğrenciye deneyi tamamen kendisi tasarlama, verileri kendileri toplama ve yorumlama gibi üst düzey süreç becerilerine yer vermemiştir. $\mathrm{Bu}$ bileşen bakımından daha da gelişmeye ihtiyaçları olduğu görülmektedir. Bununla birlikte, öğretmen adaylarının, eğitimler ve sınıf içi öğretim etkinliklerinden edindikleri deneyimler sonucunda, konunun öğretiminde değişikliğe giderek konuya özgü öğretim stratejilerine yöneldikleri de gözlemlenmiştir.

Değerlendirme bilgisi bileşeni bakımından öğretmen adaylarının eğitimlerden önce ve mikro öğretim uygulamalarından bazılarında geleneksel (testler, boşluk doldurma gibi) değerlendirme türlerini tercih ettikleri gözlemlenmiştir. Bu durum onların öğrenciliklerinde çoğunlukla bu tekniklerin kullanılarak değerlendirilmesiyle ilgilidir. Yapılan eğitimlerdeki sınıf içi tartışmalarda konulara özgü değerlendirme teknikleri tartışılmıştır. Schneider ve Plassman'ın (2011) PAB gelişim yörüngesine göre Gizem dışındaki öğretmen adaylarının tamamı gelişim göstermiş, Gizem ise aynı düzeyde kalmıştır (Grafik 5). Gizem'in hem geleneksel değerlendirme tekniklerini (test ve boşluk doldurma sorularını içeren çalışma kağıdı) hem de tamamlayıcı (portfolyo) değerlendirme kullanmış olması PAB gelişim yörüngesine göre tam olarak açıklanamadığı düşünülmektedir. Ancak sınıf içi uygulamalarda öğretmen adayları sürece dönük değerlendirme tekniklerini de kullanmaları onlar için gelişimin bir göstergesidir. Öğretmen adaylarının başlangıçta geleneksel değerlendirme tekniklerini kullanmaları Kaya'nın (2009) ve Padilla ve Van Driel'ın (2011) sonuçları ile uyumludur. Ayrıca, öğretmen adaylarının adayları çalışma kağıdı kullandıkları Friedrichsen ve diğerleri (2009) tarafından da tespit edilmiştir.

\section{Öneriler}

Öğretmen adaylarının PAB gelişimlerinin derinlemesine incelendiği bu araştırmada, Schneider ve Plassman'ın (2011) PAB gelişim yörüngesi bazı bileşenler (örn. fen öğretiminin amaç ve hedefleri bilgisi, değerlendirme bilgisi) bakımından tam olarak yorumlanamamıştır. PAB gelişim yörüngesinin daha da detaylı ve kapsamlı hale getirilebilmesi için çok sayıda teorik ve uygulamalı çalışmalara ihtiyaç olduğu düşünülmektedir. Ayrıca henüz ilköğretim düzeyinde uygulanan bir araştırmada PAB gelişim yörüngesi kullanılmamış olup sadece bu araştırmada kullanılmıştır. Dolayısıyla yapılacak her çalışmanın literatüre doğrudan katkısı olacaktır. Schneider ve Plassman'ın (2011) PAB gelişim yörüngesi öğretmen adaylarının PAB'larını tam olarak açıklayamasa da adayların gelişimlerini kendilerine göre değil de, belirli kriterlere göre tanımlanması açısından tek işlevsel yoldur. Dolayısıyla bu teorik yapının geliştirilmesine katkı sağlanmalıdır.

$\mathrm{Bu}$ araştırmada katılımcılar, alan bilgisi düzeylerine göre seçilmiştir. Ancak öz yeterlik, tutum gibi bazı duyuşsal özelliklerin PAB'1 etkilediği bilinmektedir (Hashwey 2005). Araştırmacılar bu kriterleri de temel alan başka çalışmalar tasarlayarak bu özelliklerin PAB gelişimini 
nasıl etkilediğine de bakabilirler. Çünkü $\mathrm{PAB}$ gelişim düzeylerinin belirlenmesi, öğretmen adaylarının hangi bileşen bakımından nerede oldukları ve hangi düzeye ulaştıklarında ideal $\mathrm{PAB}$ seviyesine sahip olacaklarını bilmeleri onların için motivasyon kaynağı olabilir. Öğretmen adaylarının pedagoji ve alan bilgilerine ayrı ayrı sahip olsalar bile özelikle uygulamanın başında uygun şekilde bir araya getirip tam olarak birleştiremedikleri (Aydın \& Boz 2012) bu araştırmada da görülmektedir. Dolayısıyla öğretmen eğitimi süresince PAB bileşenleri bütüncül olarak her ders kapsamında ayrı ayrı ya da bir ders olarak verilmesinin PAB gelişimine önemli katkılar sağlayacağı düşünülmektedir. Ayrıca, PAB gelişiminin ortaya konmasında literatürde var olan diğer PAB değerlendirme tekniklerinin de kullanımı bu gelişimin betimlenmesinde yararlı olabilir.

\section{KAYNAKÇA}

Abell S. K. (2008). "Twenty Years Later: Does Pedagogical Content Knowledge Remain a Useful Idea?" International Journal of Science Education 30/10 (2008) 1405-1416.

Adadan E. \& Öner D. (2014). Exploring the Progression in Preservice Chemistry Teachers' Pedagogical Content Knowledge Representations: The Case of "Behavior of Gases". Research in Science Education 44/2 (2014). Doi: 10.1007/s11165-014-9401-6.

Aydın S. \& Boz Y. (2012). "Review of Studies Related to Pedagogical Content Knowledge in the Context of Science Teacher Education: Turkish Case". Educational Sciences: Theory and Practice 12/1 (2012) 497-505.

Böke K. (2009). Sosyal Bilimlerde Araştırma Yöntemleri. Ankara 2009.

Brown P., Friedrichsen P. \& Abell S. (2012). "The Development of Prospective Secondary Biology Teachers PCK". Journal of Science Teacher Education 24/1 (2012) 133-155.

Çalık M. \& Aytar A. (2013). "Sınıf Öğretmen Adaylarının Öğretmenlik Uygulaması Sürecinde İnsanın Çevreye Etkisi Konusu ile İlgili Pedagojik Alan Bilgilerinin Araştırılması". Kuram ve Uygulamada Eğitim Bilimleri 13/3 (2012) 1-27.

De Jong O. \& Van Driel J. (2004). "Exploring the Development of Student Teachers' PCK of the Multiple Meanings of Chemistrytopics". International Journal of Science and Mathematics Education 2/4 (2004) 477-491.

De Jong O., Van Driel J. H. \& Verloop N. (2005). "Pre-Service Teachers' Pedagogical Content Knowledge of Using Particle Models in Teaching Chemistry". Journal of Research in Science Teaching 42/8 (2005) 947-964.

Ekiz D. (2009). Bilimsel Araştırma Yöntemleri: Yaklaşım, Yöntem ve Teknikler. Ankara 2009.

Fraenkel J. R. \& Wallen N.E. (2006). How to Design and Evaluate Research in Education. Boston 2006.

Friedrichsen P. J., Abell S. K., Pareja E. M., Brown P. L., Lankford D. M. \& Volkmann M. J. (2009). "Does Teaching Experience Matter? Examining Biology Teachers' Prior Knowledge for Teaching in an Alternative Certification Program". Journal of Research in Science Teaching 46/4 (2009) 357-383.

Gess-Newsome J. (1999). "Pedagogical Content Knowledge: An Introduction and Orientation". Eds. J. Gess-Newsome \& N. G. Lederman. Examining Pedagogical Content Knowledge (1999) 3-17. Dordrecht, Netherlands.

Hashweh Z. M. (2005). "Teacher Pedagogical Constructions: A Reconfiguration of Pedagogical Content Knowledge". Teachers and Teaching: Theory and Practice 11/3 (2005) 273-292.

Kaya O. (2009). "The Nature of Relationships Among the Components Pedagogical Content Knowledge of Preservice Science Teachers: "Ozon Layer Depletation" as an Example". International Journal of Science Education 31/7 (2009) 961-988.

Kind V. (2009). "Pedagogical Content Knowledge in Science Education: Perspectives and Potential for Progress". Studies in Science Education 45/2 (2009) 169-204.

Landis J. R. \& Koch G. G. (1977). "The Measurement of Observer Agreement for Categorical Data". Biometrics 33/1 (1977) 159-174. 
Loughran J., Berry A. \& Mulhall P. (2006). Understanding and Developing Science Teachers' Pedagogical Content Knowledge. Netherlands 2006.

Magnusson S., Krajcik J. \& Borko H. (1999). "Nature, Sources and Development of Pedagogical Content Knowledge for Science Teaching". Eds. J. Gess-Newsomeand \& N. G. Lederman. Examining Pedagogical Content Knowledge (1999) 95-132. Dordrecht, Netherlands.

McComas W. F. (2014). The Language of Science Education: An Expanded Glossary of Key Terms and Concepts in Science Teaching and Learning. Boston 2014.

Metcalf K., Hammer M. \& Kahlich P. (1996). "Alternatives to Field-Based Experiences: The Comperative Effects of on-Campus Laboratoires". Teaching \& Teacher Education 12/3 (1996) 271-283.

Morrison J. A. \& Lederman N. G. (2003). "Science Teachers' Diagnosis and Understanding of Students' Preconceptions". Science Education 87 (2003) 849-867.

Nargund-Joshi V., Park-Rogers M. A. \& Akerson V. (2011). "Exploring Indian Secondary Teachers' Orientation and Practice for Teaching Science in an Era of Reform". Journal of Research in Science Teaching 48/6 (2011) 624-647.

Nilsson P. (2008). "Teaching for Understanding: The Complex Nature of PCK in Pre-Service Teacher Education". International Journal of Science Education 30/10 (2008) 1281-1299.

Null W. (2011). Curriculum: From Theory to Practice. New York 2011.

Park S. \& Oliver J. S. (2008). "Revisiting the Conceptualisation of Pedagogical Content Knowledge (PCK): PCK as a Conceptual Tool to Understand Teachers as Professionals". Research in Science Education 38/3 (2008) 261-284.

Rozenszajn R. \& Yarden A. (2014). "Expansion of Biology Teachers' Pedagogical Content Knowledge (PCK) During a Long-Term Professional Development Program". Research in Science Education 44/1 (2014) 189-213.

Schneider R. M. \& Plasman K. (2011). "Science Teacher Learning Progressions: A Review of Science Teachers' Pedagogical Content Knowledge Development". Review of Educational Research 81/4 (2011) 530-565.

Shulman L. (1986). "Those Who Understand: Knowledge Growth in Teaching". Educational Researcher 15/2 (1986) 4-14.

Shulman L. S. (1987). "Knowledge and Teaching: Foundations of the New Reform". Harvard Educational Review 57/1 (1987) 1-22.

Strauss A. \& Corbin J. (1990). Basics of Qualitative Research: Grounded Theory Procedures and Techniques. Newbury Park 1990.

Van Driel J. H., Beijaard D. \& Verloop N. (2001). "Professional Development and Reform in Science Education: The Role of Teachers' Practical Knowledge". Journal of Research in Science Teaching 38/2 (2001) 137-158.

Van Driel J. H. \& Berry A. (2012). "Teacher Professional Development Focusing on Pedagogical Content Knowledge". Educational Researher 41/1 (2012) 26-28.

Van Driel J. H., Jong O. D. \& Verloop N. (2002). “The Development of Preservice Chemistryt Eachers' Pedagogical Content Knowledge". Science Education 86/4 (2002) 572-590.

Veal W. R. \& MaKinster J. G. (1999). "Pedagogical Content Knowledge Taxonomies". Electronic Journal of Science Education 3/4 (1999). Kaynak: http://wolfweb.unr.edu/homepage/crowther/ejse/ ejsev3n4.html. Erişim Tarihi: 03.08.2013.

Veal W. R., Tippins D. J. \& Bell J. (1999). The Evolution of Pedagogical Content Knowledge in Prospective Secondary Physics Teachers (No. ED443719). Indiana, USA 1999.

Yıldırım A. \& Şimşek H. (2011). Sosyal Bilimlerde Nitel Araştırma Yöntemleri. Ankara 2011.

Yin R. K. (2003). Case Study Research Design and Methods. London 2003. 
